\title{
Kinetics Approach of Biodegradation of Petroleum Contaminated Soil by using Indigenous Isolated Bacteria
}

\author{
Bambang Yudono ${ }^{1}$, Muhammad Said ${ }^{2}$, Sabaruddin $^{3}$, Adipati Napoleon ${ }^{3}$ and Zainal Fanani ${ }^{1}$ \\ ${ }^{1}$ Department of Chemistry, University of Sriwijaya, Palembang, Indonesia \\ ${ }^{2}$ Department of Chemical Engineering, University of Sriwijaya, Palembang, Indonesia \\ ${ }^{3}$ Department of Soil Science, Faculty of Agriculture, University of Sriwijaya, Palembang, Indonesia \\ Jl. Raya Palembang-Prabumulih Km 32 Indralaya South Sumatera 30662, Indonesia \\ Tel: +62711580335, Fax+62711580056, E-mail: yudonob@hotmail.com
}

Received 17 February 2010 / accepted 5 January 2011

\begin{abstract}
The bioremediation of petroleum contaminated soil was investigated using a microscale Landfarming. The Indigenous bacteria, Pseudomonas pseudoalcaligenes, Bacillus megaterium, and Xanthobacter autotrophicus were isolated from the contaminated sites Sungai Lilin Jambi Pertamina Ltd and used further in the bioremediation experiments. The biodegradation rates of petroleum contaminated soil in the presence of the isolated bacteria were studied by using the chemical kinetics approach. The reaction orders were studied by using the differential method and the reaction rate constants were studied by using the integral method. The results showed that the reaction orders were $1.0949,1.3985,0.8823$, and the reaction rate constants were $0.0189,0.0204,0.0324$ day $^{-1}$, respectively. Considering the values of reaction orders and reaction rate constants, the biodegradation rate of contaminated soil by using each bacteria had significantly different value; Xanthobacter Autotrophicus bacteria could degrade the petroleum oil sludge fastest than the others.
\end{abstract}

Keywords: Biodegradation, indigenous bacteria, kinetics, petroleum oil

\section{INTRODUCTION}

Among solid phase treatment technologies, landfarming has distinctive advantage for stimulating the native soil bacteria that are enriched in the soil by presence of contaminants but that are constrained in their degradation capability by limiting factors such as inadequate aeration, poor contact of microorganisms with the contaminants and insufficient nutrients (Hansen et al. 2004). Normally, traditional agriculture procedures are used to create mixing and aeration (tilling, bulking), to provide moisture (irrigation) and nutrients (fertilizer). Landfarming is one of the accepted method remediation processes by US EPA(US EPA 1995).

The biodegradation potential of hydrocarbons is not only defined by their chemical composition, but also by the biological, physical and chemical characteristics of the soil environment (BetancurGalvis et al. 2006). The rate at which microbial cells can covert chemicals during bioremediation processes depends on the rate of uptake and

J Trop Soils, Vol. 16, No. 1, 2011: 33-38 ISSN 0852-257X metabolism (the intrinsic activity of the cell) and the rate of transfer to the cell. Studies have shown that bacterial degradation was altered greatly by the physical and chemical features of the heterogeneous microbial environment (Tang et al. 2005).

Wide assortments of bacterial consortium, which are responsible for degradation of hydrocarbons found in petroleum contaminated soil, are aerobic bacteria. The major micro organisms responsible for biodegradation of petroleum hydrocarbons have been found to be bacteria and fungi (Boonchan et al. 2000). The genera to which hydrocarbon degrading bacteria belong are Pseudomonas, Alcaligenes, Micrococcus, Nocardia, Corynobacterium, Rhodococcus, Enterobacter, Eschrechia, Arthrobacter, Bacillus, Streptomyces, Clostredium, and Proteus (Strauss and du Plessis 2000).

Few works have been dedicated to investigate the kinetics of soil bioremediation (AntizarLadislao et al. 2005; Li et al. 2006). Information on kinetics is extremely important because it characterizes the concentration of the chemical remaining at any time and permits prediction of the levels likely to be present at some future time.

Hwang et al. (2001) investigated the bioremediation of diesel-contaminated using 
composting techniques. The results of the applied first order kinetics model agreed to a great extent with the experimental results. They found that the average first order kinetic rate constant of diesel oil was 0.099 day $^{-1}$. Antizar-Ladislao et al. (2005) have studied the biodegradation of 16 polycyclic aromatic hydrocarbons using laboratory scale invessel composting at different temperatures. The degradation took place in mixed culture of bacteria, fungi, and actinomycetes. They found out that the first order kinetics could satisfactorily describe bioremediation process and the first order kinetic constant for all contaminates ranged between 0.009 day $^{-1}$ at $70^{\circ} \mathrm{C}$ and 0.013 day $^{-1}$ at $38^{\circ} \mathrm{C}$. Li et al. (2006) studied the biodegradation of diesel contaminated soil by an isolated bacterial genus Planococcus. They used a Luong model to describe the bio reaction kinetics. The kinetic model was solved to obtain a maximum growth rate ìmax $=$ $0.34 \mathrm{~h}^{-1}$ and saturation concentration $\mathrm{Ks}=0.041$ $m M \mathrm{~L}^{-1}$.

First-order kinetics is commonly used to describe biodegradation in environmental fate models because mathematically the expression can be incorporated easily into the models (Greene $e t$ al. 2000). Many investigators grasp at first-order kinetics because of the ease of presenting and analyzing the data, the simplicity of plotting the logarithm of the chemical remaining versus time as a straight line, and the ease of predicting future concentrations (Reardon et al. 2002). In different environments, first-order constants and the number of cells able to metabolize the substrate would differ (Greene et al. 2000).

The main objectives of this work were to isolate an indigenous bacterium capable to bio remediate petroleum contaminated soil and to find out the reaction order and reaction rate kinetic constant of the biodegradation process for the purpose of specific degradation rate determination.

\section{MATERIALS AND METHODS}

\section{Site and Experiment Scale}

Bioremediation experiments of petroleum oil sludge were undertaken in small scale of $25 \mathrm{~kg}$ or the ratio is $1: 100$ from the actual bed of field scale process. The thickness of the dehydrated sludge in the prepared bed was $10 \mathrm{~cm}$.

\section{Pretreatment of the Oil Sludge}

The petroleum oil sludge collected from storage pit was put into the prepared bed. The oil sludge had heavy clay texture and low oxygen diffusivity. In order to enhance aeration and water-holding capacity of the sludge, organic and inorganic bulking materials (wood particles and sandy soil) were added. The content of wood particles in the sludge was $10.0 \%(\mathrm{w} / \mathrm{w})$ and that of sand was $10 \%(\mathrm{w} / \mathrm{w})$. Urea was provided as a nitrogen source, and potassium dehydrogenate phosphate as a phosphorus source. The ratio of C, N and P in the oil sludge was 100:10:1 after the fertilizers had been added. The initial TPH concentrations were $9.82 \%$, which diluted from the main contaminated soil sample, its concentration of Total Petroleum Hydrocarbon (TPH) of contaminated soil was $71.16 \%$.

\section{Bioremediation Process}

Microorganism were collected from the contaminated soil which the following procedure; soil samples were collected from three different petroleum contaminated sites near the Sungai Lilin Pertamina Ltd. The samples were taken from each location at depths of 5 and $10 \mathrm{~cm}$. Twenty grams of each soil sample were soaked in $100 \mathrm{ml}$ of ringer's solution $(6.5 \mathrm{~g} \mathrm{NaCl}, 0.42 \mathrm{~g}$ $\mathrm{KCl}, 0.25 \mathrm{~g} \mathrm{CaCl}_{2}$ per liter of distilled water) and shaken at $175 \mathrm{rpm}$ for $2 \mathrm{~h}$ (Boonchan et al. 2000). Samples were then allowed to settle for $24 \mathrm{~h}$ at room temperature. A volume of $5 \mathrm{ml}$ of the supernatant was used to inoculate $50 \mathrm{ml}$ of basal salt medium solution "BHMS" which consist of $\mathrm{Mg}_{2} \mathrm{SO}_{4} .7 \mathrm{H}_{2} \mathrm{O} 0.2 \mathrm{~g} \mathrm{~L}^{-1}, \mathrm{CaCl}_{2} 0.02 \mathrm{~g} \mathrm{~L}^{-1}, \mathrm{KH}_{2} \mathrm{PO}_{4}$ $1 \mathrm{~g} \mathrm{~L}^{-1}, \mathrm{~K}_{2} \mathrm{HPO}_{4} 1 \mathrm{~g} \mathrm{~L}^{-1}, \mathrm{NH}_{4} \mathrm{NO}_{3} 1 \mathrm{~g} \mathrm{~L}^{-1}, \mathrm{FeCl}_{3}$ $0.05 \mathrm{~g} \mathrm{~L}^{-1}$ dissolved in $1 \mathrm{~L}$ aquadest containing crude oil at concentration of $50 \mathrm{mg} \mathrm{L}^{-1}$.

Inoculated BHMS samples were incubated at $37^{\circ} \mathrm{C}$ for $24 \mathrm{~h}$ (Kanaly et al. 2000) and then $0.1 \mathrm{ml}$ from the suspension was plated in duplicate on Petri dishes containing basal mineral salt medium (BHMS agar). Cycloheximide (0.1 $\mathrm{g} \mathrm{L}^{-1}$ ) was added to the media in order to kill any possible existing fungi and to permit the growth of clear bacterial colonies. Petri dishes were incubated at $37^{\circ} \mathrm{C}$ for 3 days. After incubation, bacterial strain was isolated depending on the macroscopic characters of the colonies (shape, color, and size). The isolation was carried out by sub culturing of each different colony on trybticose soy agar plates and incubating at $37^{\circ} \mathrm{C}$ for $24 \mathrm{~h}$ to enhance the growth (Williams et al. 1998). The isolated bacteria were cultivated in (BHMS solution at $37^{\circ} \mathrm{C}$. This is considered as a bacterial stock that will be used as an inoculum in the further bioremediation experiments.

Identification of isolated bacteria was carried out according to the colony characteristics and 
using analytical profile index API 20 NE (Murray et al. 1995). API $20 \mathrm{NE}$ test was used as a bacterial species identification kit that encompasses 20 different biochemical tests. The results of the biochemical tests were then interpreted using bioMérieux specific code manual to identify the bacterial species.

The bioreactors were inoculated by the isolated bacterial suspension at $10 \%$ concentrations according to the specific experimental design. The concentration of micro organism in the bacterial suspension was measured using the gravimetric analysis of total suspended solid (TSS). The bacteria concentration was $10^{10} \mathrm{cfu}$. All experiments were conducted in a room temperature laboratory at temperature $\pm 25^{\circ} \mathrm{C}$. Two soil samples $\pm 5 \mathrm{~g}$ were removed every two weeks from each bioreactor to test the rate of degradation. Crude oil in soil samples was extracted using soxhlet extractor by adding $250 \mathrm{ml}$ of diethylene ether. The extraction process was finished when there was no more crude oil dissolved in the solvent.

\section{RESULTS AND DISCUSSION}

The petroleum oil sludge pollutant has many components, it can be seen in the Figure 1 and 2 the chromatogram initial condition and after 70 days incubated by using the Xanthobacter Autotrophicus bacteria. It will be very complicated to analysis each components during the biodegradation process. In order to make it simpler, the biodegradation kinetics was

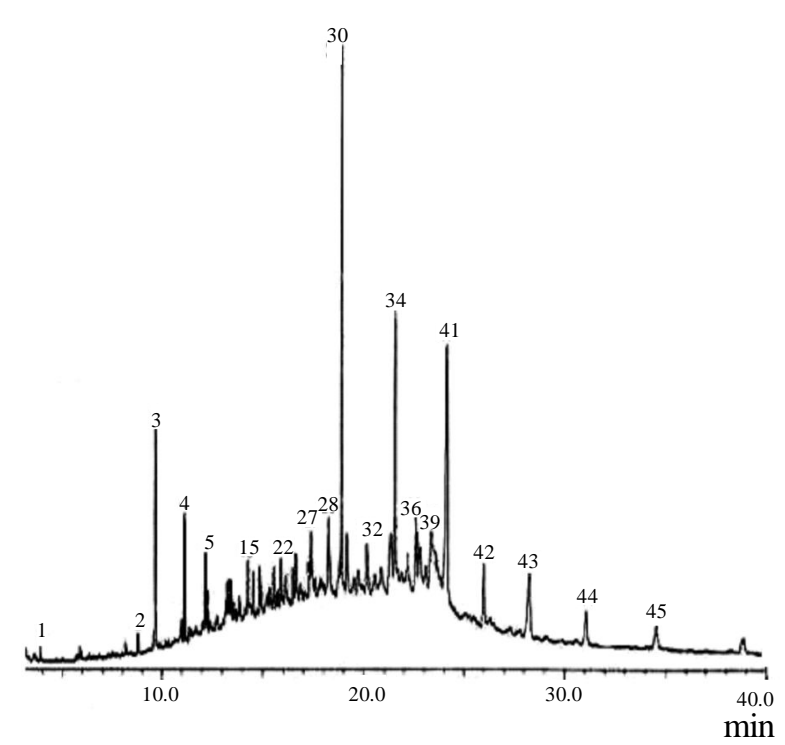

Figure 1. The Chromatogram of sample at the initial condition. calculated as the decreasing concentration of Total Petroleum Hydrocarbon (TPH).

The hydrocarbon compounds were biodegraded into carbon dioxide, water and energy (Hojae et al. 2005).

$$
\mathrm{C}_{\mathrm{n}} \mathrm{H}_{\mathrm{n}}+\mathrm{O}_{2} \underset{\text { microorganisms }}{\longrightarrow} \mathrm{CO}_{2}+\mathrm{H}_{2} \mathrm{O}+\text { Energy }
$$

The general formula of the chemical reaction kinetic that can be described as the rate of TPH reduction is:

$$
r=\frac{d C}{d t}=-k C^{n}
$$

Where:

r: reaction rate (concentration unit/time unit $=$ $\Delta \mathrm{TPH} / \Delta \tau)$

$\mathrm{t}:$ time (day)

$\mathrm{C}$ : remaining TPH concentration $\left(\mathrm{mg} \mathrm{L}^{-1}\right)$ at any time

n: reaction order

$\mathrm{k}$ : first order kinetic constant $\left(1\right.$ day $\left.^{-1}\right)$

In Equation 1, it was assumed that the microbial concentration remains constant over the entire experimentation period. Therefore, the effect of microbial concentration on the kinetics constant could be neglected.

The linearization results of the experimental data are graphically presented in Figure 2 and it is derived from Equation 1.

$$
\ln r=\ln k+n \ln c
$$

If Equation $2 \ln r$ vs $\ln \mathrm{c}$ are plotted, it will be straight line graph with the slope is $\mathrm{n}$ and the intercept is $\ln \mathrm{k}$. The rate reaction constant will be more accurate when it is determined by using integral method, and it will be discussed further in

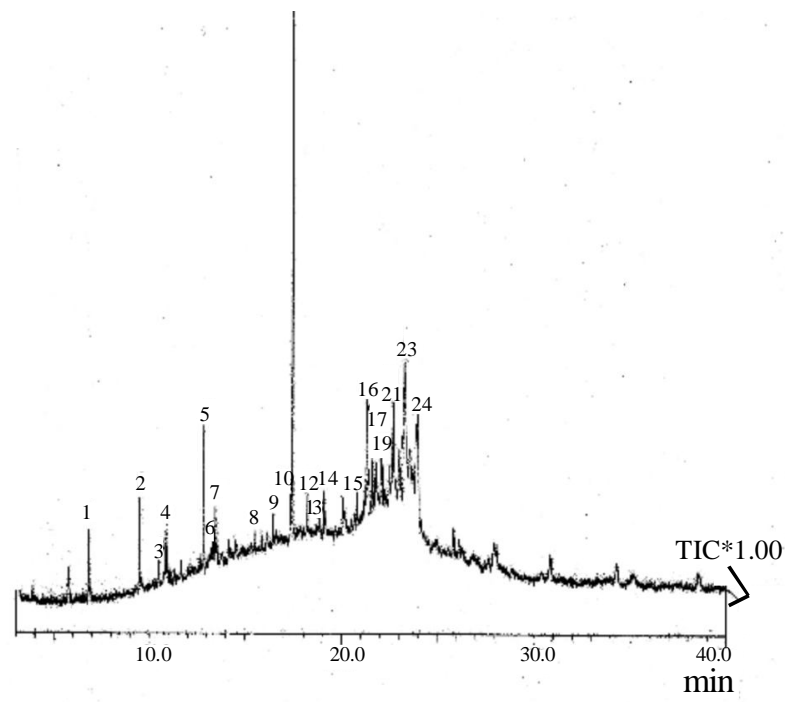

Figure 2. The chromatogram of sample after 70 days incubated by using Xanthobacter autotrophicus bacteria. 
Table 1. TPH concentration (\%) in the treated soil at initial and after 14 days incubation.

\begin{tabular}{|c|c|c|c|}
\hline \multirow{2}{*}{$\begin{array}{c}\text { Initial TPH } \\
\text { Concentration in treated } \\
\text { soil }(\%)\end{array}$} & \multicolumn{3}{|c|}{$\begin{array}{c}\text { The decreasing TPH concentration (\%) after } 14 \text { days incubated by } \\
\text { using bacteria }\end{array}$} \\
\hline & $\begin{array}{l}\text { Bacillus } \\
\text { Megaterium }\end{array}$ & $\begin{array}{l}\text { Xanthobacter } \\
\text { Autotrophicus }\end{array}$ & $\begin{array}{c}\text { Pseudomonas } \\
\text { pseudoalcaligenes }\end{array}$ \\
\hline 4.18 & 1.30 & 2.91 & 2.99 \\
\hline 6.60 & 2.48 & 4.47 & 4.74 \\
\hline 9.82 & 4.76 & 6.69 & 7.96 \\
\hline 10.87 & 5.05 & 6.84 & 8.44 \\
\hline 13.42 & 6.33 & 7.97 & 10.41 \\
\hline
\end{tabular}

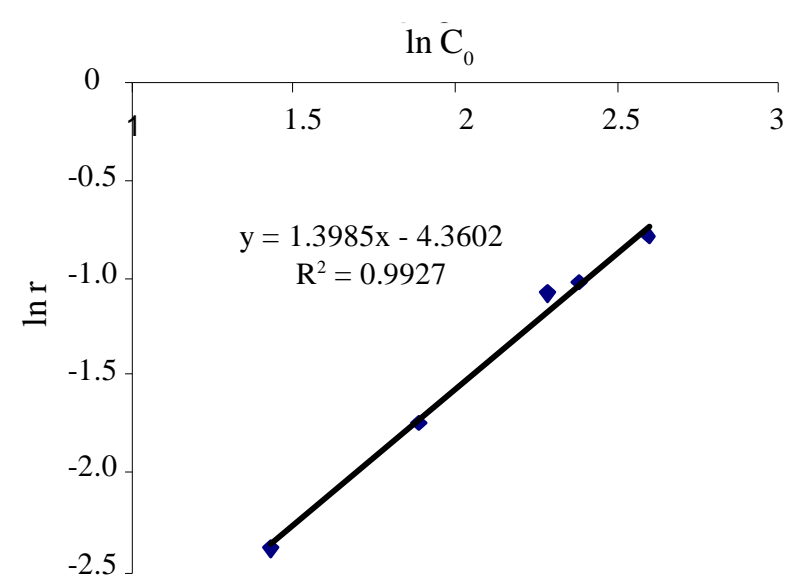

Figure 3. Graph $\ln \mathrm{C}_{0}$ vs. $\ln \mathrm{r}$ to determine reaction order treated soil by using Bacillus megaterium.

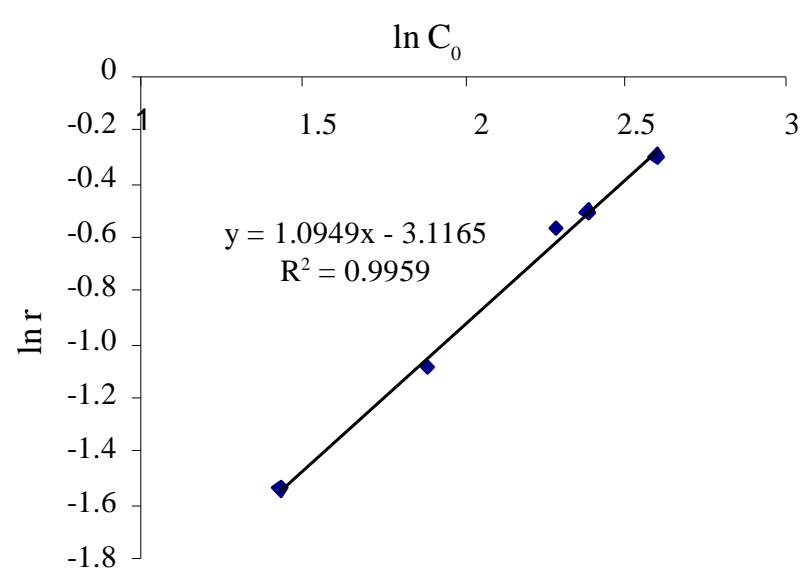

Figure 5. Graph $\ln \mathrm{C}$ vs $\ln \mathrm{r}$ to determine reaction order treated soil by using Pseudomonas pseudoalcaligenes.

determining reaction rate constant by using integral method.

The result of THP analysis in the initial and after 14 days incubated by bacteria is showed in Table 1.

According to equation 4 , the data in Table 1 are calculated as $\ln \mathrm{C}_{0}$ and $\ln \mathrm{r}$, then it is plotted into graph as shown in the Figure 3.

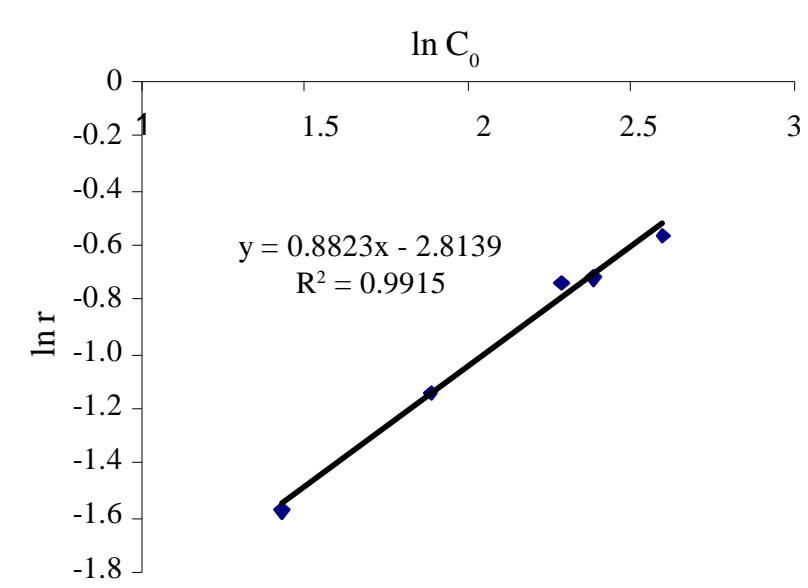

Figure 4. Graph $\ln \mathrm{C}_{0}$ vs. $\ln \mathrm{r}$ to determine reaction order treated soil by using Xanthobacter autotrophicus.

From the Figure 3, 4, and 5, and equation 4; the biodegradation reaction order of, Xanthobacter autotrophicus, Pseudomonas pseudoalcaligenes, Bacillus megaterium bacteria are 0.8823, 1.0949, and 1.3985 respectively. Generally among researchers these values are rounded up to be 1 , therefore these values are significantly different.

\section{Determination the Reaction Rate Constant by Using the Integral Method}

The integration of Equation 1 leads to the known formula of the first-order kinetics

$$
C=C_{o} e^{-k t}
$$

Where:

$\mathrm{C}_{0}$ : the initial concentration $(\mathrm{mg} / \mathrm{l})$ or $\mathrm{TPH}_{0}$

In order to experimentally calculate the kinetic constant k, Eq. 3 is linearized using the following equation

$$
\begin{aligned}
& \ln \frac{C_{0}}{C}=k t \\
& \ln T P H=-k t+\ln T P H_{0}
\end{aligned}
$$


Table 2. The TPH concentration in treated soil after incubated by using bacteria.

\begin{tabular}{cccc}
\hline \multirow{2}{*}{ Time (day) } & \multicolumn{3}{c}{ TPH Concentration (\%) in soil treated by bacteria } \\
\cline { 2 - 4 } & $\begin{array}{c}\text { Xanthobacter } \\
\text { autotrophicus }\end{array}$ & $\begin{array}{c}\text { Bacillus } \\
\text { megaterium }\end{array}$ & $\begin{array}{c}\text { Pseudomonas } \\
\text { pseudoalcaligenes }\end{array}$ \\
\hline 0 & 9.82 & 9.82 & 9.82 \\
14 & 6.69 & 4.77 & 7.96 \\
28 & 3.00 & 3.60 & 4.06 \\
42 & 2.10 & 3.18 & 3.90 \\
56 & 1.56 & 2.79 & 3.56 \\
70 & 1.06 & 1.89 & 2.52 \\
\hline
\end{tabular}

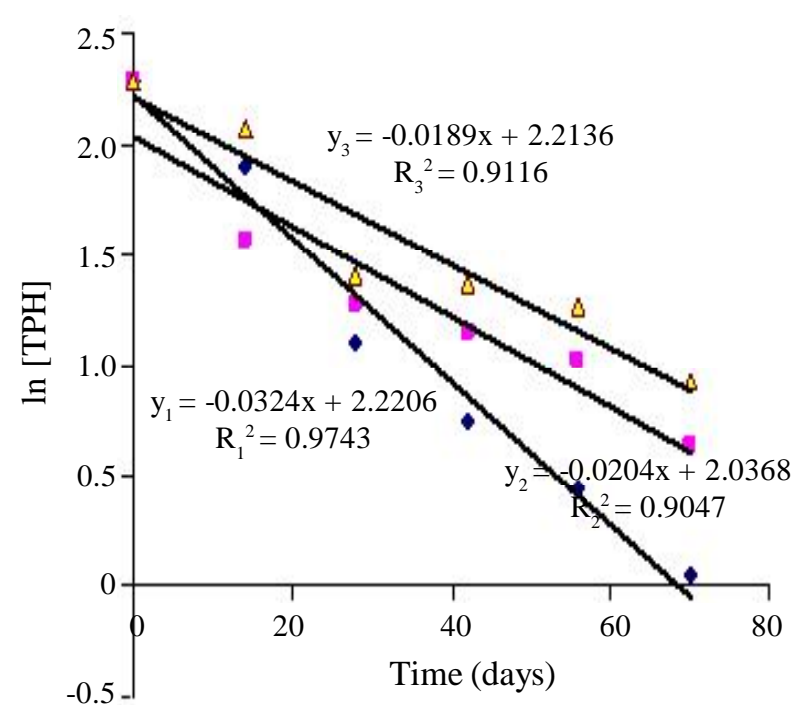

Figure 6. Graph $\ln [\mathrm{TPH}]$ vs Time to determine reaction rate constant. $\bullet=$ Xanthobacter autotrophicus, $=$ Bacillus megaterium, and $\Delta=$ Pseudomonas pseudoalcaligenes.

The initial concentration of sample was 9.82 $\%$; it was inoculated by using Bacillus megaterium, Xanthobacter autotrophicus, Pseudomonas pseudoalcaligenes bacteria. It had been observed during $0,14,28,42,56$, and 70 days, the decreasing TPH concentrations in the treated soil were shown in Table 2.

Based on the equation 7, the data were plotted the logarithmic part of Equation 7 versus time. Analysis of the rates of hydrocarbons removal showed that most compounds obeyed first-order kinetics (Greene et al. 2000). The slope of the line represents the first-order kinetic constant $\mathrm{k}$.

Considering on the Figures 3, 4, 5, and 6, the values of reaction orders and reaction rate constants are shown in the Table 3

When the reaction is assumed as first order reaction, the reaction rate is determined by the value of reaction rate constant. Based on the reaction rate constant value, the Xanthobacter autotrophicus
Table 3. The kinetics biodegradation parameters of bacteria.

\begin{tabular}{lcc}
\hline \multirow{2}{*}{ Bacteria } & \multicolumn{2}{c}{ The kinetics parameters } \\
\cline { 2 - 3 } & $\mathrm{n}$ & $\mathrm{k}\left(\right.$ day $\left.^{-1}\right)$ \\
\hline $\begin{array}{l}\text { Xanthobacter } \\
\text { Autotrophicus }\end{array}$ & 0.8823 & 0.0324 \\
$\begin{array}{l}\text { Pseudomonas } \\
\text { pseudoalcaligenes }\end{array}$ & 1.0949 & 0.00189 \\
Bacillus Megaterium & 1.3985 & 0.0204 \\
\hline
\end{tabular}

bacteria can degradate the TPH in the petroleum oil sludge fastest among the others. Similar results were found in previous studies that were conducted on bioremediation of petroleum contaminated soil (Bock et al. 1994; Strauss and du Plessis 2000; Boonchan et al. 2000; Barathi and Vasudevan 2001; Bassim and Shquirat 2008). However, the reaction rate can be calculated more detail by using the real reaction orders as described in th Table 3 . These calculation can be explained as following equation.

The equation 1 is converted into integral equation:

$$
\begin{aligned}
& -\frac{d[C]}{d t}=-k[C]^{\mathrm{n}} \ldots \ldots \ldots \\
& \int_{C_{0}}^{C_{t}}[C]^{-n} d[C]=-k \int d t
\end{aligned}
$$

Table 4. The kinetics approach of biodegradation of petroleum contaminated soil.

\begin{tabular}{ll}
\hline Bacteria biodegrader & $\begin{array}{l}\text { The Kinetics Approach of } \\
\text { Biodegradation }\end{array}$ \\
\hline $\begin{array}{l}\text { Xanthobacter } \\
\text { autotrophicus }\end{array}$ & $\mathrm{C}_{\mathrm{t}}^{0.117}=\mathrm{C}_{0}^{0.117}-0.117 . \mathrm{kt}$ \\
$\begin{array}{l}\text { Bacillus megaterium } \\
\text { Pseudomonas }\end{array}$ & $\mathrm{C}_{\mathrm{t}}^{-0.3985}=\mathrm{C}_{0}^{-0.3985}+0.3985 . \mathrm{kt}$ \\
pseudoalcaligenes & $\mathrm{C}_{\mathrm{t}}^{-0.0949}=\mathrm{C}_{0}^{-0.0949}+0.0949 . \mathrm{kt}$ \\
\hline
\end{tabular}


The integral equation results:

$$
[C]_{t}^{(-n+1)}=[C]_{0}^{(-n+1)}-(-n+1) . k . t
$$

When each the reaction order value is inserted into the Equation 8, so the Kinetics Approach of Biodegradation of Petroleum Contaminated Soil are described in the Table 4.

\section{CONCLUSIONS}

Considering the values of reaction orders and reaction rate constants, the biodegradation rate of contaminated soil by using each bacteria had significantly different value; Xanthobacter Autotrophicus bacteria could degrade the petroleum oil sludge faster than the others.

\section{REFERENCES}

Antizar-Ladislao B, J Lopez-Real and AJ Beck. 2005. Laboratory studies of the remediation of polycyclic aromatic hydrocarbon contaminated soil by invessel composting. Waste Manag 25: 281-289.

Barathi S and N Vasudevan. 2001. Utilization of petroleum hydrocarbon by Pseudomonas fluorescens isolated from a petroleum contaminated soil. Environ Int 26 (5): 413-416.

Bassim EA and WD Shquirat. 2008. Kinetics of indegenous isolated bacteria used for ex-situ bioremediation of petroleum contaminated soil. Water Air Soil Pollut 192: 221-226.

Betancur-Galvis LA, D Alvarez-Bernal, AC RamosValdivia and L Dendooven. 2006. Bioremediation of polycyclic aromatic hydrocarbon-contaminated saline-alkaline soils of the former Lake Texcoco. Chemosphere 62: 1749-1760.

Bock M, K Kampfer and W Dott. 1994. Isolation and characterization of heterotrophic aerobic bacteria from oil storage caverns in northern Germany. Appl Microbiol Biotech 42: 463-468.

Boonchan S, ML Britz and GA Stanley. 2000. Degradation and mineralization of high-molecularweight polycyclic aromatic hydrocarbons by defined fungalbacterial cocultures. Appl Environ Microbiol 66 (3): 1007-1019.

Greene EA, JG Kay, K Jaber, G Stehmeier and G Voordouw. 2000. Composition of soil microbial communities enriched on a mixture of aromatic hydrocarbons. Appl Environ Microbiol 66 (12): 5282-5289.

Hansen LD, C Nestler, D Ringelberg and R Bajpai. 2004. Extended bioremediation of PAH/PCP contaminated soils from the POPILE wood treatment facility. Chemosphere 54: 1481-1493.

Hojae S, H Byungho, L Sang-Seob and K Sung-Ho. 2005. Kinetics of BTX biodegradation by a coculture of Pseudomonas putida and Pseudomonas fluorescencens under hypoxic conditions. Biodegradation 16: 319-327.

Hwang E, W Namkoong and J Park. 2001. Recycling of remediated soil for effective composting of dieselcontaminated soil. Compost Sci Util 9 (2): 143-149.

Kanaly RA, R Bartha, K Watanabe and S Harayama. 2000. Rapid mineralization of benzopyrene by a microbial consortium growing on diesel fuel. Appl Environ Microbiol 66: 4205-4211.

Li H, YH Liu, N Luo, XY Zhang, TG Luan and JM Hu. 2006. Biodegradation of benzene and its derivatives by a psychrotolerant and moderately haloalkaliphilic Planococcus sp. Strain ZD22. Res Microbiol 157: 629-636.

Murray PR, EJ Baron, MA Pfaller, FC Tenover and RH Yolke. 1995. Manual of Clinical Microbiology, Vol $6^{\text {th }}$ ed. ASM, Washington, DC.

Reardon KF, DC Mosteller, JB Rogers, NM DuTeau and K Kee-Hong. 2002. Biodegradation kinetic of aromatic hydrocarbon mixtures by pure and mixed bacterial cultures. Environ Health Perspect 110 (12):1005-1012.

Strauss JM and CA du Plessis. 2000. Empirical model for biofiltration of toluene. J Environ Eng 126 (7): 644-648.

Tang Y, JL Qi and B Krieger-Brockett. 2005. Evaluating factors that influence microbial henanthrene biodegradation rates by regression with categorical variables. Chemosphere 59: 729-741.

USEPA. 1995. Cost and performance report: slurry phase bioremediation application at the Southeastern Wood Preserving Superfund Site Canton, Mississippi. Report contract Number: 68-W3-0001

Williams DL, KD Kriel, GA Stewart, RC Hulse, JE Holsomback and JR Stewart. 1998. Bioremediation of oil-contaminated soils by stimulating indigenous microbes. Environ Geosci 5 (1): 1-9. 